\title{
ANALISIS PEMBELAJARAN BELA DIRI MILITER DI SMAN TARUNA NALA JAWA TIMUR TERHADAP SUDUT PANDANG STANDAR PROSES PENDIDIKAN DASAR DAN MENENGAH
}

\author{
Lu'luil Maknuunah', Zainul Abidin' ${ }^{2}$, Saida Ulfa ${ }^{3}$ \\ Jurusan Teknologi Pendidikan, Fakultas Ilmu Pendidikan, Universitas Negeri Malang \\ Jl. Semarang 5 Malang 65145 - 0341-574700 \\ E-mail: luluilmaknuunah17@gmail.com
}

\begin{abstract}
ABSTRAK
Bela Diri Militer merupakan implementasi kurikulum Bela Negara dan Kemaritiman di SMAN Taruna Nala Jawa Timur. Kurikulum Bela Negara dan Kemaritiman merupakan kurikulum pendamping kurikulum 2013 yang keduanya saling terintegrasi. Kurikulum Bela Negara dan Kemaritiman memiliki standar proses pelaksanaan yang tercantum dalam dokumen kurikulum Pendidikan Bela Negara dan Kemaritiman, sedangkan kurikulum 2013 memiliki standar proses yang diatur oleh Permendikbud Nomor 22 Tahun 2016. Penelitian ini dilaksanakan untuk menganalisis pembelajaran Bela Diri Militer terhadap sudut pandang standar proses pendidikan dasar dan menengah (Permendikbud Nomor 22 Tahun 2016). Metode penelitian yang diterapkan pada penelitian ini adalah metode deskriptif kualitatif. Hasil penelitian memaparkan bahwa desain pembelajaran Bela Diri Militer tidak sama seperti desain pembelajaran berdasarkan Permendikbud Nomor 22 Tahun 2016, pelaksanaan pembelajaran Bela Diri Militer secara umum sama seperti pelaksanaan pembelajaran berdasarkan Permendikbud Nomor 22 Tahun 2016, penilaian hasil pembelajaran Bela Diri Militer secara umum sama seperti pelaksanaan pembelajaran berdasarkan Permendikbud Nomor 22 Tahun 2016 meskipun tanpa penilaian proses pembelajaran, dan pengawasan oleh assessor tidak dilaksanakan untuk mata pelajaran Bela Diri Militer
\end{abstract}

Kata kunci : standar proses pembelajaran, desain, pelaksanaan, penilaian, pengawasan.

\section{PENDAHULUAN}

Kurikulum dan pembelajaran adalah dua pembahasan yang tidak dapat dipisah satu sama lain. Kurikulum mempengaruhi keberhasilan proses pembelajaran, begitu pula proses pembelajaran menentukan keberhasilan sebuah kurikulum. Kurikulum pendidikan seharusnya bersifat dinamis. Alasan ini lah yang menjadikan kurikulum pendidikan selalu menjadi pembahasan yang selalu memiliki urgensi tinggi dari waktu ke waktu.

Pengembangan kurikulum sudah sewajarnya terjadi secara terus-menerus secara berkelanjutan. Kurikulum yang dilaksanakan di setiap sekolah atau satuan pendidikan pun tidak harus sama, namun menyesuaikan kebutuhan masing-masing satuan pendidikan. Namun, pemerintah telah menetapkan sebuah kurikulum nasional, yaitu kurikulum 2013, yang otoritas pengembangan lebih lanjutnya bersifat desentralisasi. Meski demikian, pengembangan kurikulum khusus seharusnya tidak aneh lagi di dunia pendidikan.

SMAN Taruna Nala Jawa Timur telah mengembangkan sebuah kurikulum bernama Kurikulum Bela Negara dan Kemaritiman. Kurikulum Bela Negara dan Kemaritiman di SMAN Taruna Nala Jawa Timur dikembangkan sebagai kurikulum kedua yang mendampingi kurikulum 2013 sebagai kurikulum nasional. Kurikulum Bela Negara dan Kemaritiman adalah kurikulum berbasis kecakapan hidup yang dikembangkan oleh tim pengembang dari Angkatan Laut yang bertugas di SMAN Taruna Nala Jawa Timur. Kedua kurikulum yang diterapkan di SMAN Taruna Nala tersebut saling terintegrasi. Kurikulum Bela Negara dan Kemaritiman memiliki standar proses yang tercantum dalam dokumen Kurikulum Pendidikan Bela Negara dan dokumen Kurikulum 
Pendidikan Kemaritiman, sedangkan kurikulum 2013 menganut standar proses yang dibuat oleh pemerintah kementerian pendidikan dalam Permendikbud Nomor 22 Tahun 2016. Kurikulum Bela Negara dan Kemaritiman diterapkan untuk semua tingkatan kelas dengan mata pelajaran yang berbeda pada setiap semester. Sehingga, pada setiap semester, siswa akan menempuh dua jenis pembelajaran sekaligus, yaitu pembelajaran kurikulum 2013 dan pembelajaran kurikulum Bela Negara dan Kemaritiman. Memang seharusnya kurikulum berjalan sesuai dengan standar proses masing-masing, namun tidak menutup kemungkinan dua kurikulum yang terlaksana beriringan memiliki pelaksanaan yang hampir sama demi terlaksananya pembelajaran yang serasi. Penelitian ini bertujuan untuk menganalisis pembelajaran Bela Diri Militer yang merupakan implementasi kurikulum Bela Negara dan Kemaritiman untuk kelas $\mathrm{X}$ semester genap ditinjau dari sudut pendang standar proses pendidikan dasar dan menengah, yaitu Permendikbud Nomor 22 Tahun 2016.

\section{KAJIAN TEORI}

\section{Kurikulum dan Pembelajaran}

Dalam buku Arifin (2011) dijelaskan bahwa kata "kurikulum" (curriculum) diambil dari bahasa Yunani, yaitu kata curir yang memiliki arti pelari dan curere yang berarti tempat berpacu. Kata kurikulum lahir dari bidang atletik di bidang olahraga pada zaman Romawi Kuno di Yunani. Sedangkan dalam bahasa Perancis, kurikulum didapatkan dari kata courier yang memiliki makna berlari (to run). Kurikulum berarti sebuah jarak tempuh untuk atlit pelari dari garis mulai (start) hingga selesai (finish). Jarak tempuh tersebut kemudian diibaratkan sebagai program atau strategi yang disusun oleh sekolah untuk dilaksanakan sejak awal masuk sekolah hingga lulus. Kurikulum adalah sebuah perencanaan kegiatan yang dirancang untuk pembelajaran siswa, baik di dalam maupun di luar sekolah, untuk mencapai tujuan pendidikan. Tujuan pendidikan dijelaskan visi dan misi pendidikan nasional dalam UndangUndang Nomor 20 Tahun 2003. Secara singkat, tujuan pendidikan nasional adalah untuk mewujudkan sistem pendidikan yang kokoh dan berwibawa demi sumber daya manusia (warga) Indonesia yang berwibawa, sehingga warga Indonesia menjadi warga yang berkualitas dan mampu menjawab tantangan perkembangan zaman.

Pengertian pembelajaran dari pendapat Gagne dan Briggs dalam buku Idi (2006) adalah upaya yang dilakukan oleh guru, instruktur, pembelajar dengan tujuan untuk membantu siswa atau peserta didik (learners: siswa, pebelajar, peserta didik) supaya bisa belajar dengan mudah. Menurut Hendratmoko (2017), Kegiatan atau praktik pembelajaran dirancang dengan tujuan untuk memfasilitasi pebelajar mencapai suatu kompetensi atau tujuan pembelajaran tertentu . Jadi, kurikulum merupakan program pembelajaran, sedangkan pembelajaran merupakan bentuk nyata atau implementasi dari susuna program pembelajaran (kurikulum) yang telah dibuat.

\section{Standar Pendidikan Dasar dan Menengah}

Standar pendidikan dasar dan menengah berdasarkan permendikbud mengatur beberapa hal, yaitu desain pembelajaran, pelaksanaan pembelajaran, penilaian proses dan hasil pembelajaran, dan pengawasan pembelajaran.

\section{Desain Pembelajaran}

Desain pembelajaran terdiri dari dua komponen, yaitu silabus dan Rencana Pelaksanaan Pembelajaran (RPP). Berdasarkan Permendikbud Nomor 22 Tahun 2016, Silabus adalah tolok ukur pembuatan kerangka pembelajaran pada setiap bahan kajian mata pelajaran yang memuat identitas mata pelajaran atau tema pelajaran, identitas sekolah, kompetensi 
inti, kompetensi dasar, tema, materi pokok, pembelajaran, penilaian, alokasi waktu, dan sumber belajar. Sedangkan RPP adalah perencanaan kegiatan pembelajaran yang sistematis untuk minimal satu pertemuan tatap muka. RPP memuat identitas mata pelajaran, identitas sekolah, kelas/semester, materi pokok, alokasi waktu, tujuan pembelajaran (gambaran hasil belajar yang diharapkan berdasarkan kompetensi dasar, ditulis dengan memakai kata kerja operasional yang dapat diukur mencakup pengetahuan, sikap, dan keterampilan), kompetensi dasar (sejumlah kemampuan yang harus dikuasai oleh siswa pada mata pelajaran tertentu), materi pembelajaran (memuat fakta, konsep, prosedur, prinsip sesuai dengan indikator pencapaian kompetensi), metode pembelajaran yang digunakan oleh guru, media pembelajaran yang digunakan dalam kegiatan pembelajaran, sumber belajar (dapat berupa cetak atau elektronik), langkahlangkah pembelajaran yang sistematis (meliputi kegiatan pendahuluan, kegiatan inti, dan kegiatan penutup), dan penilaian hasil pembelajaran.

\section{Pelaksanaan Pembelajaran}

Pelaksanaan pembelajaran yang diatur dalam Permendikbud Nomor 22 Tahun 2016 meliputi persyaratan pelaksanaan pembelajaran dan proses pelaksanaan pembelajran. Syarat alokasi waktu yang ditentukan adalah 45 menit untuk satu kali jam pelajaran. Jumlah siswa maksimal adalah 36 siswa untuk setiap kelas dengan jumlah kelas maksimal 6 kelas. Sedangkan kegiatan pelaksanaan yang diatur adalah kegiatan pendahuluan, kegiatan inti, dan kegiatan penutup. Pada kegiatan pendahuluan, guru wajib menyiapkan fisik dan psikis siswa. Kedua, guru wajib memberi motivasi belajar kepada siswa sesuai dengan manfaat dan aplikasi materi. Ketiga, guru wajib mengajukan pertanyaan berkaitan dengan materi yang akan dipelajari. Keempat, guru wajib menjelaskan tujuan pembelajaran.
Terakhir, guru wajib menyampaikan cakupan materi.

Penilaian Proses dan Hasil Pembelajaran

Permendikbud Nomor 22 Tahun

2016 mengatur penilaian proses pembelajaran dilakukan saat proses pembelajaran berlangsung dengan menggunakan alat lembar pengamatan, angket sebaya, rekaman, catatan anekdot, dan refleksi. Sedangkan penilaian hasil pembelajaran dilaksanakan saat proses pembelajaran di akhir satuan pembelajaran menggunakan tes lisan/praktik dan tes tulis. Hasil penilaian akhir didapatkan dari gabungan data penilaian proses dan data penilaian hasil pembelajaran.

\section{Pengawasan Pembelajaran}

Pengawasan pembelajaran diatur dalam Permendikbud Nomor 22 Tahun 2016 dengan menerapkan prinsip objekif dan transparan. Tahapan yang dilaksanakan adalah pemantauan yang dilakukan pada tahap perencanaan, pelaksanaan, dan penilaian hasil pembelajaran; supervisi yang dilakukan pada tahap perencanaan, pelaksanaan, dan penilaian hasil pembelajaran; pelaporan; dan tindak lanjut yang berupa penghargaan atau pemberian kesempatan guru untuk mengikuti program pengembangan keprofesionalan berkelanjutan.

\section{METODE PENELITIAN}

Metode penelitian yang digunakan adalah penelitian deskriptif menggunakan pendekatan kualitatif. Teknik pengumpulan data yang digunakan adalah wawancara, observasi, dan dokumentasi. Fokus penelitian adalah pada desain pembelajaran, pelaksanaan pembelajaran, penilaian proses dan hasil pembelajaran, dan pengawasan pembelajaran. Data terkait desain pembelajaran diperoleh dari wawancara staf ahli kurikulum dan guru mata pelajaran Bela Diri Militer serta dokumentasi arsip. Data pelaksanaan pembelajaran diperoleh dari hasil 
observasi, wawancara siswa dan guru mata pelajaran Bela Diri Militer, dan dokumentasi. Data penilaian proses dan hasil belajar siswa diperoleh dari hasil wawancara staf ahli kurikulum dan guru mata pelajaran Bela Diri Militer, dokumentasi arsip, dan observasi. Sedangkan data pengawasan diperoleh dari wawancara kepala sekolah, staf ahli kurikulum, dan dokumentasi arsip. Pengecekan keabsahan data menggunakan teknik triangulasi. Menurut Moleong (2004), Triangulasi adalah sebuah teknik untuk memeriksa keabsahan data dengan memanfaatkan sesuatu yang lain. Metode triangulasi yang dilakukan pada penelitian ini adalah triangulasi dengan sumber dengan cara membandingkan data hasil wawancara dengan data hasil pengamatan (observasi) dan membandingkan hasil wawancara dengan isi dokumen terkait.

\section{HASIL DAN PEMBAHASAN}

\section{Desain Pembelajaran}

Hasil penelitian menunjukkan bahwa silabus mata pelajaran Bela Diri Militer berbentuk dokumen kurikulum, perbedaan silabus mata pelajaran Bela Diri Militer dan silabus pada Permendikbud Nomor 22 Tahun 2016 terletak pada kompetensi inti, kompetensi dasar, tema, materi pokok, pembelajaran, penilaian, dan sumber belajar. Silabus mata pelajaran Bela Diri Militer masih dalam tahap pengembangan. Hal ini dikarenakan SMAN Taruna Nala yang masih baru berdiri dengan konsep yang juga masih baru dikembangkan.

Rencana Pelaksanaan Pembelajaran mata pelajaran Bela Diri Militer berbentuk sebaran tabel materi untuk setiap pertemuan. Perbedaan RPP mata pelajaran Bela Diri Militer dengan berdasarkan Permendikbud Nomor 22 Tahun 2016 terletak pada kompetensi dasar, metode pembelajaran, media pembelajaran, sumber belajar, langkah-langkah pembelajaran, dan penilaian. RPP mata pelajaran Bela Diri Militer tidak memuat komponen-komponen tersebut.

\section{Pelaksanaan Pembelajaran}

Dalam permendikbud nomor 22 tahun 2016, alokasi waktu untuk pendidikan menengah SMA/MA adalah 45 menit untuk satu jam tatap muka mata pelajaran. Mata pelajaran Bela Diri Militer kelas 10 SMAN Taruna Nala terjadwal pukul 14.15 - 15.45 WIB untuk hari Selasa (X MIPA 4 dan X IPS) dan Rabu (X MIPA 1 dan X MIPA 5) dan pukul 13.30 - 15.00 untuk hari Kamis (X MIPA 2 dan X MIPA $3)$. Artinya, satu kali pertemuan adalah 2 jam tatap muka dengan rincian 45 menit dalam satu jam pelajaran tatap muka. Alokasi waktu jam pelajaran Bela Diri Militer sama seperti ketetapan dalam Standar Pendidikan Dasar dan Menengah (Permendikbud Nomor 22 Tahun 2016).

Dalam permendikbud nomor 22 tahun 2016 disebutkan bahwa untuk satuan pendidikan menengah SMA/MA, jumlah rombongan belajar yang diperbolehkan adalah 3-36 rombongan belajar. Sedangkan jumlah maksimal siswa/peserta didik untuk setiap rombongan belajar adalah 36 orang siswa. Mata pelajaran Bela Diri Militer diikuti oleh 178 siswa kelas 10.178 siswa tesebut tersebar ke dalam 6 kelas dengan rincian X MIPA 1 ada 31 orang siswa, 31 orang siswa di kelas X MIPA 2, 28 orang siswa di kelas X MIPA 3, 29 orang siswa di kelas X MIPA 4, 30 orang siswa di kelas X MIPA 5, dan 29 orang siswa di kelas X IPS. Artinya, rombongan belajar mata pelajaran Bela Diri Militer sama seperti ketetapan dalam Standar Pendidikan Dasar dan Menengah (Permendikbud Nomor 22 Tahun 2016).

Pembelajaran Bela Diri Militer menggunakan buku teks berjudul Shotokan KARATE (International) KATA (Vol.1) yang ditulis oleh Hirokazu Kanazawa. Pemanfaatan buku tersebut diatur oleh instruktur. Tidak semua materi dipelajari, hanya beberapa jurus saja yang dianggap cocok untuk diterapkan dalam mata pelajaran Bela Diri Militer saja. Buku tersebut pun tidak dimiliki oleh seluruh siswa karena untuk menyesuaikan 
kebutuhan, maka siswa diberikan copy materi dari buku tersebut sesuai kebutuhan menjelang ujian untuk kebutuhan latihan mandiri. Dalam hal ini, artinya, buku teks pelajaran diartikan digunakan sesuai kebutuhan guru dan siswa.

Pada kegiatan pendahuluan, instruktur selalu menyiapkan kesiapan siswa untuk mengikuti pelajaran/latihan, instruktur memberikan motivasi kepada siswa, instruktur menjelaskan secara singkat materi/jurus yang akan dipelajari pada pertemuan tersebut. Kegiatan pendahuluan yang dilaksanakan oleh instruktur mata pelajaran Bela Diri Militer ini sesuai dengan apa yang tercantum dalam permendikbud nomor 22 tahun 2016 bahwa guru wajib menyiapkan kesiapan psikis dan fisik peserta didik, memberi motivasi kepada peserta didik, dan menyampaikan cakupan materi. Namun, terdapat kriteria yang tidak dilaksanakan oleh instruktur, yaitu menjelaskan kompetensi dasar kepada siswa dan mengajukan pertanyaan terkait materi sebelumnya dan yang akan dipelajari. Hal ini dikarenakan menyesuaikan kebutuhan teknis pembelajaran. Meski demikian, instruktur menggantikannya dengan mereview secara praktikal gerakan yang diajarkan sebelumnya

Pada kegiatan inti, instruktur selalu memberikan contoh gerakan jurus baru kepada siswa dan diikuti oleh siswanya. Gerakan tersebut diulang-ulang hingga siswa dapat mempraktikkannya. Hal ini merupakan perwujudan dari isi permendikbud nomor 22 tahun 2016 bahwa keterampilan diperoleh melalui kegiatan mengamati, menanya, mencoba, menalar, dan menyaji. Siswa mula-mula dijelaskan nama dan cara mempraktikkan gerakannya. Kemudian instruktur memberi contoh gerakan dan siswa mengikutinya. Tahapan ini disebut mengamati. Siswa juga diperbolehkan bertanya jika ada yang belum memahami konsep gerakan. Kemudian, siswa akan melakukan latihan secara berkelompok dengan pendampingan instruktur. Tahapan ini disebut mencoba dan menalar. Hingga kemudian siswa mencoba mempraktikkannya secara mandiri, yaitu menyaji.

Sedangkan pada kegiatan penutup, instruktur selalu memberikan evaluasi terhadap pelaksanaan pembelajaran/latihan pada hari tersebut, instruktur juga memberikan penjelasan singkat tentang materi untuk pertemuan berikutnya. Kegiatan penutup yang dilaksanakan oleh instruktur sesuai dengan kriteria yang tercantum dalah Permendikbud Nomor 22 Tahun 2016, yaitu bahwa guru bersama peserta didik melakukan evaluasi rangkaian kegiatan pembelajaran, guru memberikan umpan balik terhadap proses dan hasil pembelajaran, serta guru memberikan informasi tentang rencana kegiatan di pertemuan berikutnya. Namun, satu kriteria yang tidak dilaksanakan pada mata pelajaran Bela Diri Militer, yaitu pelaksanaan tindak lanjut oleh guru dalam bentuk pemberian tugas baik individu maupun kelompok. Hal ini tidak dilaksanakan oleh instruktur mata pelajaran Bela Diri Militer karena konsep pembelajaran tidak membutuhkan penugasan di luar jam pembelajaran yang telah dijadwalkan.

Penilaian yang dilaksanakan pada mata pelajaran Bela Diri Militer adalah penilaian hasil pembelajaran yang berupa tes praktik yang dilaksanakan selama 4 kali. Penghitungan nilai akhir hasil belajar siswa adalah rata-rata dari nilai empat kali tes, pengamatan instruktur, dan pengamatan siswa asisten. Jika dilihat dari sudut pandang Permendikbud Nomor 22 Tahun 2016, pelaksanaan penilaian pembelajaran pada mata pelajaran Bela Diri Militer sama seperti yang diatur pada peraturan tersebut dalam hal penilaian hasil pembelajara. Dalam hal penilaian proses pembelajaran, mata pelajaran Bela Diri Militer tidak melaksanakannya.

Pengawasan pembelajaran menerapkan prinsip praktis, sistematis, objektif, realistis, antisipatif, konstruktif, kooperatif, kekeluargaan, demokratis, aktif, humanis, berkesinambungan, 
terpadu, komprehensif, dan transparan. Prinsip yang diterapkan tersebut telah memenuhi kriteria prinsip pengawasan yang tercantum dalam permendikbud nomor 22 tahun 2016, yaitu prinsip objektif dan transparan. Pelaksanaan pengawasan pembelajaran dilakukan oleh tim assessor dan kepala sekolah yang pembagian tugasnya berdasarkan rumpun mata pelajaran. Pengawasan dilaksanakan melalui tahap pemantauan, tahap supervisi, tahap pelaporan, dan tahap tindak lanjut, namun pengawasan tersebut dilaksanakan pada pembelajaran kurikulum 2013, tidak dilaksanakan pada pembelajaran Bela Diri Militer. Pengawasan kepada instruktur mata pelajaran Bela Diri Militer tidak dilaksanakan karena yang bersangkutan adalah instruktur yang berasal dari luar sekolah (undangan)

\section{KESIMPULAN}

\section{Desain Pembelajaran}

Secara keseluruhan, desain pembelajaran, baik silabus maupun Rencana Pelaksanaan Pembelajaran untuk mata pelajaran Bela Diri Militer sebagai implementasi kurikulum Bela Negara dan Kemaritiman di SMAN Taruna Nala disimpulkan tidak sama seperti desain pembelajaran yang diatur pada Permendikbud nomor 22 tahun 2016 untuk kurikulum nasional. Letak perbedaan berada pada komponen-komponen yang tercantum di dalam dokumen silabus dan dokumen Rencana Pelaksanaan Pembelajaran.

\section{Pelaksanaan Pembelajaran}

Meskipun Bela Diri Militer merupakan implementasi dari kurikulum Bela Negara dan Kemaritiman, namun pelaksanaan pembelajaran mata pelajaran Bela Diri Militer di SMAN Taruna Nala secara keseluruhan disimpulkan sama seperti pelaksanaan pembelajaran yang tercantum pada Permendikbud Nomor 22 Tahun 2016 tentang standar proses pelaksanaan pembelajaran kurikulum nasional, meliputi prasyarat yang berupa alokasi waktu, jumlah rombongan belajar, buku teks pelajaran, pengelolaan kelas dan laboratorium, kegiatan pendahuluan, kegiatan inti, dan kegiatan penutup. Adapun beberapa kriteria memang tidak sama persis, yaitu penugasan dan penjelasan materi. Kondisi tersebut terjadi dikarenakan mata pelajaran Bela Diri Militer merupakan mata pelajaran praktikal yang tidak banyak membutuhkan penjelasan materi dan penugasan.

\section{Penilaian Proses dan Hasil Pembelajaran}

Penilaian hasil pembelajaran yang dilaksanakan pada mata pelajaran Bela Diri Militer sama seperti ketentuan pelaksanaan penilaian yang tercantum dalam Permendikbud Nomor 22 Tahun 2016, yaitu melalui tes praktik. Sedangkan ketentuan kedua untuk pelaksanaan kurikulum nasional tersebut, yaitu penilaian proses pembelajaran, tidak dilaksanakan pada mata pelajaran Bela Diri Militer.

\section{Pengawasan Pembelajaran}

Sebagai implementasi kurikulum Bela Negara dan Kemaritiman, pada mata pelajaran Bela Diri Militer tidak dilaksanakan pengawasan pembelajaran baik oleh kepala sekolah maupun oleh pengawas seperti yang tercantum pada Permendikbud Nomor 22 Tahun 2016 tentang pengawasan untuk pembelajaran kurikulum nasional.

\section{DAFTAR PUSTAKA}

Arifin, Zainal. 2011. Konsep dan Model Pengembangan Kurikulum. Bandung: PT. Remaja Rosda Karya.

Hendratmoko, T., Kuswandi, D., \& Setyosari, P. Tujuan Pembelajaran Berlandaskan Konsep Pendidikan Jiwa Merdeka Ki Hajar Dewantara. JINOTEP, 3 (2), 152157. 
Idi, Abdullah. 2006. Pengembangan Kurikulum, Teori \& Praktik. Yogyakarta: Ar-Ruzz Media.

Moleong, Lexy J. 2004. Metodologi Penelitian Kualitatif. Bandung: PT. Remaja Rosda Karya.
Undang-Undang Republik Indonesia Nomor 20 Tahun 2003 tentang Sistem Pendidikan Nasional.

Peraturan Menteri Pendidikan dan Kebudayaan Nomor 22 Tahun 2016 tentang Standar Proses Pendidikan Dasar dan Menengah. 